\title{
Intracellular $\mathrm{NH}_{4}^{+}$and $\mathrm{NO}_{3}^{-}$pools associated with deposited phytoplankton in a marine sediment (Aarhus Bight, Denmark)
}

\author{
Erik Lomstein ${ }^{*}$, Mikael Hjorth Jensen, Jan Sørensen** \\ Department of Ecology and Genetics, University of Aarhus, Ny Munkegade, DK-8000 Aarhus C, Denmark
}

\begin{abstract}
Concentration profiles of $\mathrm{NH}_{4}$ and $\mathrm{NO}_{3}^{-}$in pore water and particulate matter were determined at high spatial resolution ( $\mathrm{mm}$ scale) in surface sediment from a coastal bay area (Aarhus Bight, Denmark) at $15 \mathrm{~m}$ depth during an annual cycle. Pore water pools of $\mathrm{NH}_{4}^{+}$and $\mathrm{NO}_{3}^{-}$were always considerably lower than particulate pools in the surface sediment. Particulate $\mathrm{NH}_{4}^{+}$and $\mathrm{NO}_{3}^{-}$were apparently intracellular pools in deposited microalgae and were extracted after freezing sediment samples in liquid $\mathrm{N}_{2}\left(-196^{\circ} \mathrm{C}\right.$ ). Pore water $\mathrm{NH}_{4}^{+}$and most of the adsorbed (KCl-extractable) $\mathrm{NH}_{4}^{+}$were also extracted by the freezing technique, and an estimate of the intracellular $\mathrm{NH}_{4}^{+}$pool was obtained by difference. In the absence of an adsorbed $\mathrm{NO}_{3}^{-}$pool, intracellular $\mathrm{NO}_{3}^{-}$was determined by subtraction of the pore water pool from the liquid $\mathrm{N}_{2}$-extractable pool. Highest concentrations of intracellular $\mathrm{NH}_{4}^{+}$and $\mathrm{NO}_{3}^{-}$were always observed in the upper $2 \mathrm{~mm}$ of sediment, declining sharply with depth. A distinct seasonal maximum for both pools, ca $200 \mathrm{nmol} \mathrm{cm} \mathrm{c}^{-3}$ at 0 to $2 \mathrm{~mm}$ depth, appeared after sedimentation of a phytoplankton bloom in early spring, and should be compared to a minimum of only $25 \mathrm{nmol} \mathrm{cm} \mathrm{cm}^{-3}$ or less in fall and winter. The freeze-extraction technique is proposed for a reliable estimate of intracellular $\mathrm{NH}_{4}^{+}$and $\mathrm{NO}_{3}^{-}$pools in surface sediments rich in microalgae, and may thus be used as an indicator of sedimentation of phytoplankton blooms. The significance of intracellular pools for sediment nitrogen cycling is discussed.
\end{abstract}

\section{INTRODUCTION}

In marine sediments, $\mathrm{NH}_{4}^{+}$appears both in the pore water and bound to clay minerals or organic matter. Adsorbed $\mathrm{NH}_{4}^{+}$can be extracted in an exchange reaction with $\mathrm{K}^{+}$ions ( $\mathrm{KCl}$-extractable or exchangeable $\mathrm{NH}_{4}^{+}$), but if $\mathrm{NH}_{4}^{+}$is structurally incorporated into the interlayers of clay minerals (fixed $\mathrm{NH}_{4}^{+}$) the pool is extractable only by treatment with hot hydrofluoric acid (Bremner et al. 1967, Rosenfeld 1979). In contrast, adsorbed $\mathrm{NO}_{3}^{-}$pools are unlikely to exist in sediments, and in studies of $\mathrm{NO}_{3}^{-}$transformations attention has so far only been given to $\mathrm{NO}_{3}^{-}$dissolved in pore water.

- Present address: Department of Forage Crops, Danish Research Service for Plant and Soil Science, Foulum, DK8830 Tjele, Denmark

- Addressee for correspondence; present address: Department of Microbiology, Royal Veterinary and Agricultural University, Rolighedsvej 21, DK-1958 Frederiksberg C, Denmark
Both monocultures and naturally occurring phytoplankton populations of marine microalgae have been shown to contain intracellular pools of $\mathrm{NH}_{4}^{+}$and $\mathrm{NO}_{3}^{-}$ (Dortch et al. 1985 and references therein). For instance, pelagic diatoms such as Skeletonema costatum which often dominate the spring blooms of primary production in temperate coastal waters may internally contain considerable amounts of inorganic nitrogen (e.g. Dortch 1982, Thoresen et al. 1982, Dortch et al. 1984, Raimbault \& Mingazinni 1987). Since mass sedimentation of a phytoplankton bloom may result in a large and sudden input of viable microalgae to the coastal sea floor (Sundbäck \& Jönsson 1988, Pett 1989), it is likely that significant intracellular pools of $\mathrm{NH}_{4}^{+}$and $\mathrm{NO}_{3}^{-}$appear in the surface sediment following such events. However, such pools have not been considered in sediment studies related to nutrient cycling. Both $\mathrm{NH}_{4}^{+}$and $\mathrm{NO}_{3}^{-}$are key compounds in the nitrogen cycling and organic diagenesis in sediments, and it is therefore important to quantify the role of such inorganic nitrogen pools in the microbial nitrogen transformations. 
The objective of the present study was to demonstrate and quantify the presence of particulate, intracellular pools of $\mathrm{NH}_{4}^{+}$and $\mathrm{NO}_{3}^{-}$in the surface sediment of a coastal bay area, characterized by extensive sedimentation after a phytoplankton bloom in spring. A freeze-extraction technique was developed for an assay of such intracellular inorganic nitrogen pools in sediment. During an annual cycle, undisturbed cores of the surface sediment were sectioned at mm-thick depth intervals and profiles of pore water, and adsorbed and intracellular $\mathrm{NH}_{4}^{+}$and $\mathrm{NO}_{3}^{-}$were measured. The study took place in parallel to an investigation of fluxes and concentration gradients of $\mathrm{NH}_{4}^{+}$and $\mathrm{NO}_{3}^{-}$at the sediment-water interface (Jensen et al. 1990).

\section{MATERIALS AND METHODS}

Study site and sampling. The investigation was carried out between September 1987 and August 1988 at a $15 \mathrm{~m}$ deep site in Aarhus Bight (Stn 16 of Jensen et al. 1988, 1990) in the southwestern Kattegat. Sampling was most intensive during spring, when cores were collected 2 to 4 times per month. The macro-infauna was relatively scarce; bivalves (Abra alba) and poly- chaetes (Nephtys spp.) were most abundant throughout the investigation period.

Undisturbed sediment samples were collected with a 'Haps' bottom corer (Kanneworff \& Nicolaisen 1973), from which a number of subcores were taken into Plexiglas tubes and carefully brought to the laboratory. Only cores with an undisturbed sediment surface were used. The cores were kept for a few hours in the dark at the in situ temperature before processing.

Sediment sectioning and chemical analysis. The overlying water was carefully removed from the sediment cores and a small subcore was taken into a $20 \mathrm{ml}$ disposable syringe (i.d. $2 \mathrm{~cm}$ ) with cut-off ends (Fig. 1). Each subcore was sectioned into $0-2,2-4,4-7,7-10$, $10-15,15-20,20-30$ and $30-40 \mathrm{~mm}$ depth intervals by cutting with a razor blade. This allowed fine-sectioning of the core with only slight disturbance of the sediment surface.

Specific density (weight of $1 \mathrm{~cm}^{3}$ fresh sediment) and water content (weight loss after 24 h at $105^{\circ} \mathrm{C}$ ) were determined in duplicate for each depth interval. The sediment porosity, as determined by multiplication of specific density and water content, decreased from 0.89 at $0-2 \mathrm{~mm}$ depth to 0.80 at $30-40 \mathrm{~mm}$ depth.

The following techniques were used for extraction of

I

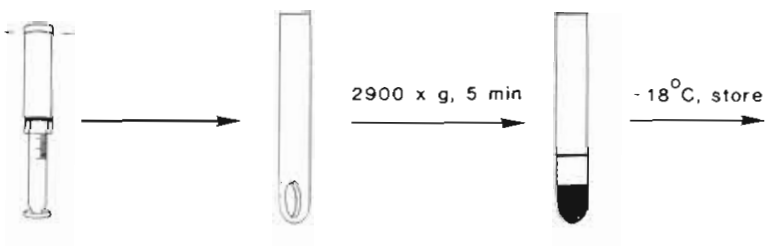

II

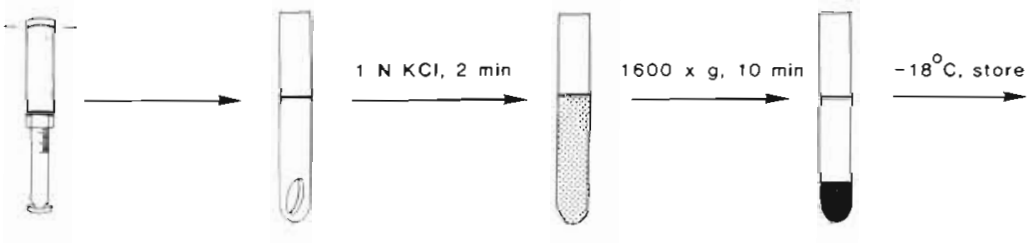

III

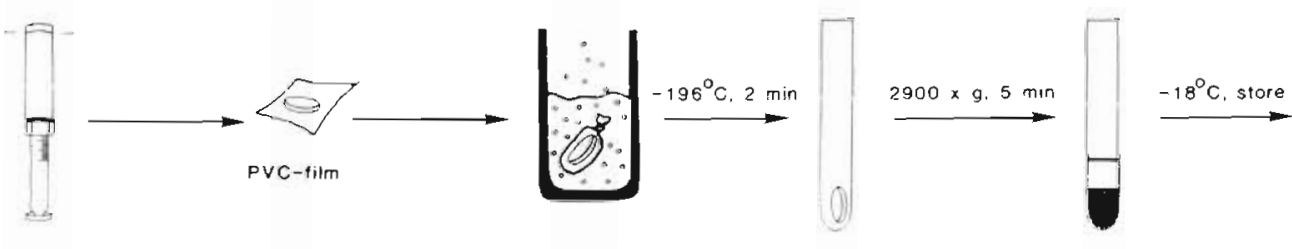

IV

Fig. 1. Flow chart of the procedures used for determination of $\mathrm{NH}_{4}^{+}$and $\mathrm{NO}_{3}^{-}$pools in the sediment. 1: Centrifugation (pore water pool); II: $\mathrm{KCl}$ extraction; III: liquid $\mathrm{N}_{2}$ extraction; IV: ethanol extraction 
$\mathrm{NH}_{4}^{+}$and $\mathrm{NO}_{3}^{-}$pools in the sediment (Fig. 1). Pore water pool (I): Each segment was centrifuged for 5 min at $2900 \times g$ and the supernatant frozen for later analysis. $\mathrm{KCl}$-extractable pool (II): Each segment was placed in ca 2 volumes of $1 \mathrm{~N} \mathrm{KCl}$ solution, shaken vigorously for $2 \mathrm{~min}$ and centrifuged at $1600 \times g$ for $10 \mathrm{~min}$. The supernatant was frozen for later analysis. Liquid nitrogen-extractable pool (III): Each segment was wrapped into a piece of PVC-film and quickly frozen in liquid $\mathrm{N}_{2}$ $\left(-196^{\circ} \mathrm{C}\right)$. The segment was then thawed during a centrifugation at $2900 \times g$ for $5 \mathrm{~min}$ and the supernatant frozen for later analysis. Ethanol-extractable pool (IV, only $\mathrm{NO}_{3}^{-}$): Each segment was treated with 5 volumes of $96 \%$ ethanol, shaken vigorously for $1 \mathrm{~min}$ and centrifuged at $1600 \times \mathrm{g}$ for $10 \mathrm{~min}$. The supernatant was transferred to a centrifuge tube and dried at $65^{\circ} \mathrm{C}$ for $24 \mathrm{~h}$. The dry matter was then dissolved in $50 \% n$-pentanol, and the green chlorophyll pigments in the $n$-pentanol phase discarded. The water phase containing the $\mathrm{NO}_{3}^{-}$was frozen for later analysis.

The samples were analyzed for $\mathrm{NH}_{4}^{+}$(Solorzano 1969) and $\mathrm{NO}_{3}^{-}$(Armstrong et al. 1967) using an autoanalyzer. All concentrations were determined in triplicate ( 3 segments from 3 different cores were used to obtain a concentration for a particular depth interval).

\section{RESULTS}

\section{$\mathrm{NH}_{4}^{+}$and $\mathrm{NO}_{3}^{-}$pools in the sediment}

An example of in situ profiles of dissolved and particulate $\mathrm{NH}_{4}^{+}$and $\mathrm{NO}_{3}^{-}$is shown in Fig. 2. On this particular sampling date ( 7 April 1988), a flocculent layer of deposited diatoms was apparent on the sediment surface indicating that sedimentation of the spring bloom had occurred immediately before the sampling occasion (Jensen et al. 1990). It should be noted that the pools extracted by $\mathrm{KCl}$ (II) and by freezing in liquid $\mathrm{N}_{2}$ (III) include the $\mathrm{NH}_{4}^{+}$and $\mathrm{NO}_{3}^{-}$in pore water. The pore water pool of $\mathrm{NH}_{4}^{+}$was smaller than the $\mathrm{KCl}$-extractable pool at all depths (Fig. 2A), but interestingly, the freezing in liquid $\mathrm{N}_{2}$ extracted 2 to 4 times more $\mathrm{NH}_{4}^{+}$ than treatment with $\mathrm{KCl}$ in the upper 2 segments. The dissolved $\mathrm{NO}_{3}^{-}$pool was relatively small and was depleted or near the detection limit at depths below $1 \mathrm{~cm}$ (Fig. 2B). Treatments of the uppermost segments with $\mathrm{KCl}$ and liquid $\mathrm{N}_{2}$, however, extracted much more $\mathrm{NO}_{3}^{-}$than was found in the pore water.

Relationships between the pools of $\mathrm{NH}_{4}^{+}$and $\mathrm{NO}_{3}^{-}$ extracted by $\mathrm{KCl}$ (II) and by freezing in liquid $\mathrm{N}_{2}$ (III) are shown in Fig. 3. The pore water concentrations are here subtracted and the data thus represent $\mathrm{NH}_{4}^{+}$and $\mathrm{NO}_{3}^{-}$associated with sediment particles, either adsorbed or occurring intracellularly in algae, bac-

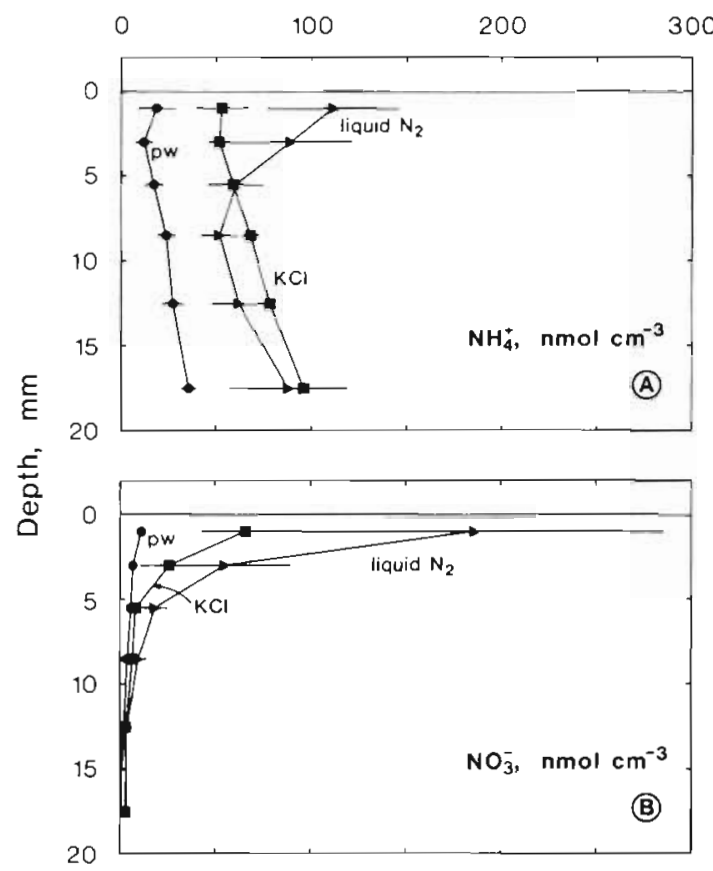

Fig. 2. (A) $\mathrm{NH}_{4}^{+}$and (B) $\mathrm{NO}_{3}^{-}$profiles in Aarhus Bight sediment (Stn 16). ( $\bullet$ Pore water concentration; and pools extracted ( ) by freezing in liquid $\mathrm{N}_{2}$ and $(-)$ by $\mathrm{KCl}$ on 7 April 1988. Standard errors of the mean $(\mathrm{n}=3)$ are indicated

teria, etc. The data were taken from the seasonal study at Stn 16 and represent all seasons; for clarity, only results from 0 to $2 \mathrm{~mm}$ and 20 to $40 \mathrm{~mm}$ depth are presented.

The $\mathrm{KCl}$-extractable $\mathrm{NH}_{4}^{+}$pool was low in the upper $2 \mathrm{~mm}$ and relatively constant irrespective of the considerable variation in the $\mathrm{NH}_{4}^{+}$pool obtained by freezing (Fig. 3A). The 2 techniques obviously extracted 2 different pools of particulate $\mathrm{NH}_{4}^{+}$in the surface sediment. Deeper in the sediment, at 20 to $40 \mathrm{~mm}$ depth, the $\mathrm{KCl}$ treatment always extracted slightly more $\mathrm{NH}_{4}^{+}$ than the freezing technique. This suggests that a relatively constant and large fraction of the $\mathrm{KCl}$-extractable $\mathrm{NH}_{4}^{+}$is also extracted by freezing. Similarly, Yamada et al. (1987) found that freezing and subsequent thawing release the exchangeable $\mathrm{NH}_{4}^{+}$pool to the interstitial water. Both an exchangeable $\mathrm{NH}_{4}^{+}$pool and an $\mathrm{NH}_{4}^{+}$pool only extractable by freezing seemed to be present in the surface sediment, while the latter pool was unimportant in the deeper part of the sediment. As most of the $\mathrm{KCl}$-extractable $\mathrm{NH}_{4}^{+}$was also extracted by freezing, a surface-located pool of particulate, but not $\mathrm{KCl}$-extractable, $\mathrm{NH}_{4}^{+}$was represented by the liquid $\mathrm{N}_{2}$-extractable pool minus the $\mathrm{NH}_{4}^{+}$pool in the $\mathrm{KCl}$ extract. Based on the data from deeper fractions (Fig. 3A), this particulate $\mathrm{NH}_{4}^{+}$pool could possibly be underestimated by up to $20 \%$ by the difference estimate, since not all exchangeable $\mathrm{NH}_{4}^{+}$was extracted by freezing. 


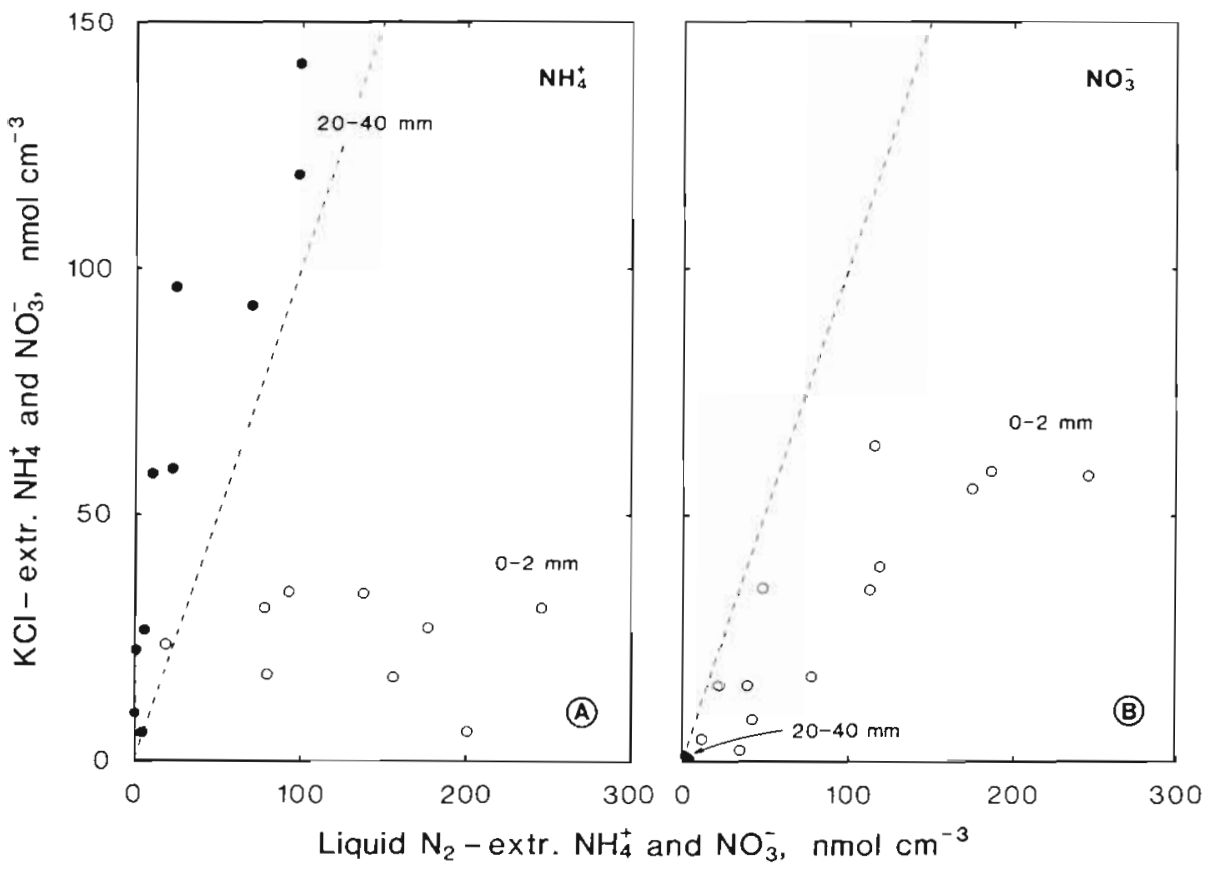

Fig. 3. Concentrations of $\mathrm{KCl}-\mathrm{ex}$ tractable (A) $\mathrm{NH}_{4}^{+}$and (B) $\mathrm{NO}_{3}^{-}$ plotted against $\mathrm{NH}_{4}^{+}$and $\mathrm{NO}_{3}^{-}$concentrations obtained by liquid $\mathrm{N}_{2-}$ freezing (Stn 16. Aarhus Bight). Pore water contents of $\mathrm{NH}_{4}^{+}$and $\mathrm{NO}_{3}^{-}$are subtracted. Concentrations are means of triplicate determinations for $(0) 0$ to $2 \mathrm{~mm}$ depth and $(\bullet 20$ to $40 \mathrm{~mm}$ depth made during a whole season. Broken lines indicate $1: 1$ ratio

Unlike for $\mathrm{NH}_{4}^{+}$, there seemed to be a quantitative relationship between $\mathrm{NO}_{3}^{-}$extracted by $\mathrm{KCl}$ and by freezing in liquid $\mathrm{N}_{2}$ for the upper $2 \mathrm{~mm}$ (Fig. 3B). the $\mathrm{KCl}$ treatment thus extracted a small but relatively constant fraction (ca $25 \%$ ) of the $\mathrm{NO}_{3}^{-}$pool obtained by freezing in liquid $\mathrm{N}_{2}$. Additional $\mathrm{NO}_{3}^{-}$could not be extracted when freezing was followed by $\mathrm{KCl}$ extraction (data not shown). This indicates that the 2 techniques extracted the same $\mathrm{NO}_{3}^{-}$pool throughout the sediment. Further evidence to support the presence of a particulate $\mathrm{NO}_{3}^{-}$pool came from a comparison of sediment samples frozen in liquid $\mathrm{N}_{2}$ and extracted in ethanol (IV), respectively. Samples originating from 0 to 2,2 to 4 and 4 to $7 \mathrm{~mm}$ depth (cores collected in September and October 1987) showed essentially the same quantities of $\mathrm{NO}_{3}^{-}$extracted by the 2 techniques (Fig. 4). Results indicate that the sediment contained a distinct particulate $\mathrm{NO}_{3}^{-}$pool located at or close to the sediment-water interface. In the deeper sediment layers, none of the techniques could detect $\mathrm{NO}_{3}^{-}$beyond the pore water pool. The surface-located particulate $\mathrm{NO}_{3}^{-}$pool was thus quantified by subtracting the $\mathrm{NO}_{3}^{-}$ pool in the pore water from the liquid $\mathrm{N}_{2}$-extractable pool. The pool could be extracted either by freezing in liquid $\mathrm{N}_{2}$ or by extraction in ethanol, but the former is clearly the simplest for routine analyses.

\section{Seasonal variation of $\mathrm{NH}_{4}^{+}$and $\mathrm{NO}_{3}^{-}$pools}

Seasonal patterns of dissolved and surface-located particulate $\mathrm{NH}_{4}^{+}$and $\mathrm{NO}_{3}^{-}$are shown by the isopleth

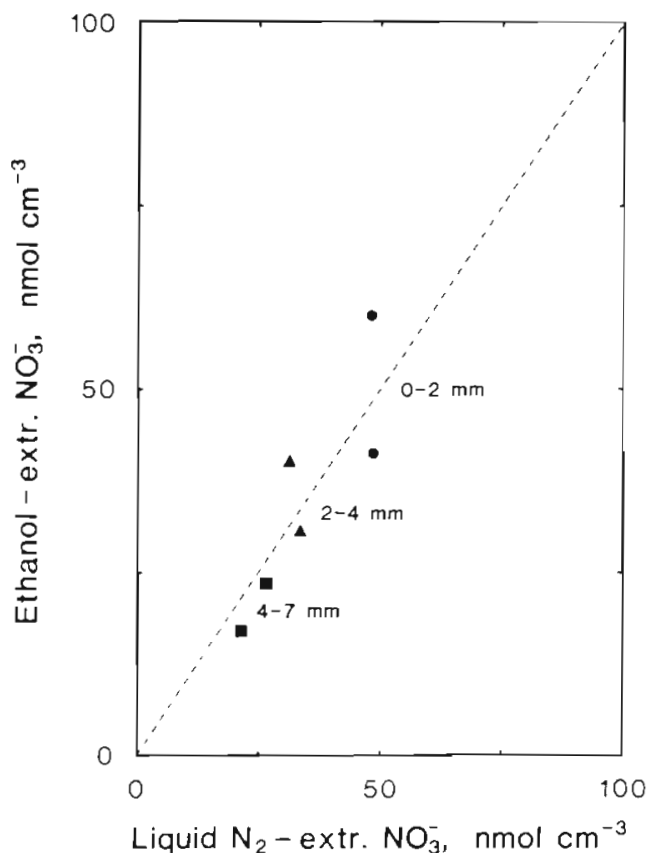

Fig. 4. Concentrations of ethanol-extractable $\mathrm{NO}_{3}^{-}$plotted against lıquid $\mathrm{N}_{2}$-extractable $\mathrm{NO}_{3}^{-}$in sediment from $\mathrm{Stn} 16$. Aarhus Bight (September and October 1987). Pore water contents are subtracted. Concentrations are means of triplicate determinations for ( 0 ) to $2 \mathrm{~mm}$ depth, (\$) 2 to $4 \mathrm{~mm}$ depth and (-) 4 to $7 \mathrm{~mm}$ depth. Broken linc indicates 1:1 ratio

diagrams in Figs. 5 and 6 . The production and sedimentation period of the spring phytoplankton bloom is indicated by the shaded area; the length of this period is judged from the time course of $\mathrm{NO}_{3}^{-}$ 
Fig. 5. Iso-concentration $(\mu \mathrm{M})$ diagram of pore water (A) $\mathrm{NH}_{4}^{+}$ and (B) $\mathrm{NO}_{3}^{-}$in Aarhus Bight sediment (Stn 16) during the investigation period (1987 to 1988). Shaded area indicates the production and sedimentation period of the spring phytoplankton bloom

Fig. 6. Iso-concentration (nmol $\mathrm{cm}^{-3}$ ) diagram of particulate (intracellular) (A) $\mathrm{NH}_{4}^{+}$and (B) $\mathrm{NO}_{3}^{-}$ in Aarhus Bight sediment (Stn 16) during the investigation period (1987 to 1988). Shaded area as in Fig. 5
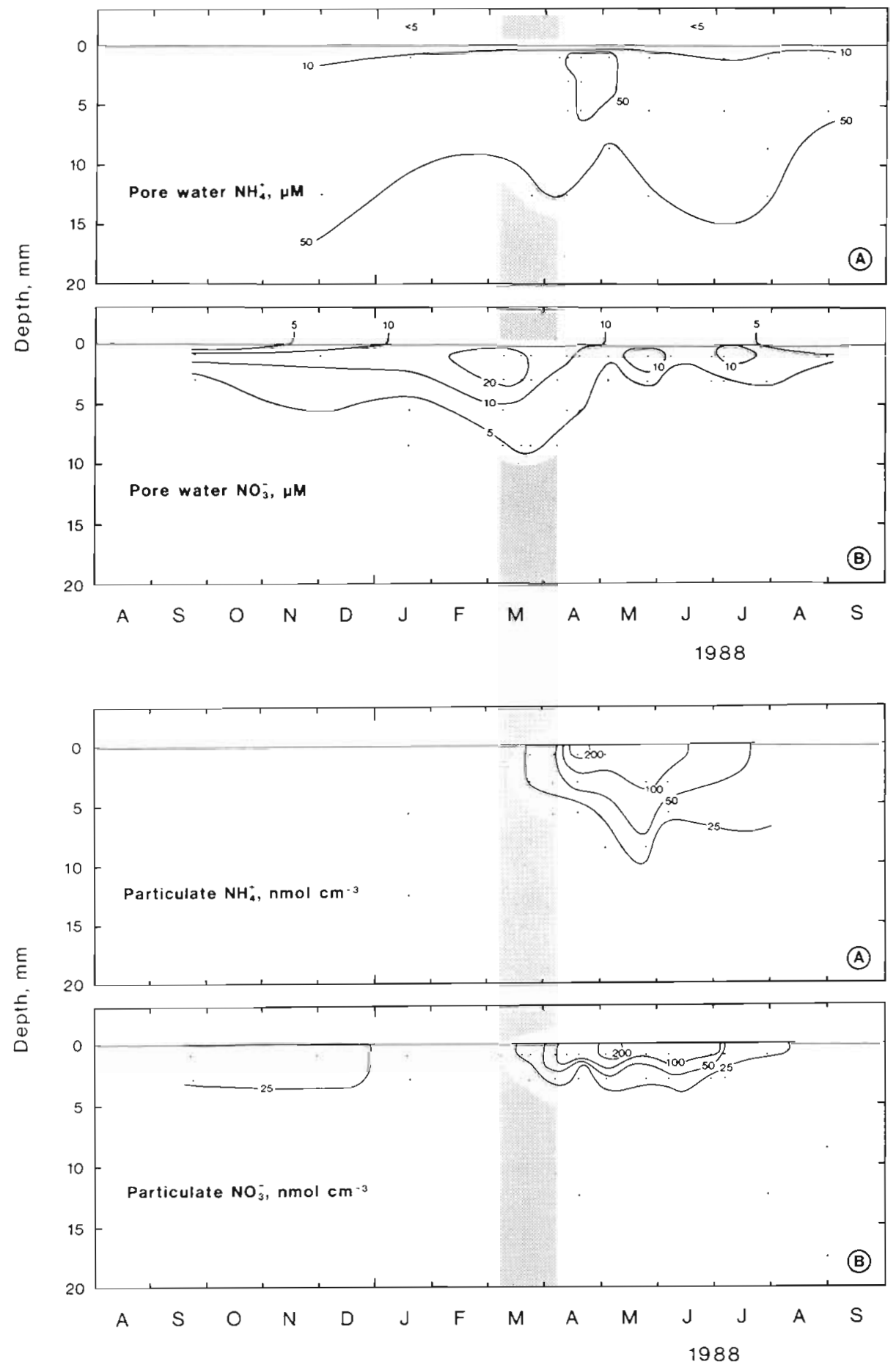

shown). The low concentration of ca $10 \mu \mathrm{M}$ at 0 to $2 \mathrm{~mm}$ depth was interrupted for 1 to 2 mo immediately after the sedimentation, when a peak of more than $50 \mu \mathrm{M}$ was observed. There was a marked seasonal variation in the dissolved $\mathrm{NO}_{3}^{-}$pool (Fig. 5B). A maximum was found either in the uppermost 0 to $2 \mathrm{~mm}$ of the sediment or in the bottom water. During winter, bottom
$5 \mathrm{~A}$ ). The $100 \mu \mathrm{M}$ isoline was found at 30 to $40 \mathrm{~mm}$ depth throughout the investigation period (data not consumption in the surface water and from visual inspection of the surface sediment (Jensen et al. 1990).

The pore water typically showed decreasing $\mathrm{NH}_{4}^{+}$ concentrations towards the sediment surface except for a short period after spring bloom sedimentation (Fig. 
water and pore water concentrations were typically high (up to 15 and $25 \mu \mathrm{M} \mathrm{NO}_{3}^{-}$, respectively), and also the penetration depth was high. After sedimentation of the spring bloom, both the concentration and the penetration depth of $\mathrm{NO}_{3}^{-}$decreased and remained relatively low throughout the summer. From late summer, bottom water as well as pore water concentrations were very low ( $5 \mu \mathrm{M}$ or less).

The surface-located particulate $\mathrm{NH}_{4}^{+}$pool was small during the winter (less than $25 \mathrm{nmol} \mathrm{cm}^{-3}$ ), but increased considerably in the uppermost sediment after the spring sedimentation (Fig. 6A). The pool size was thus ca $200 \mathrm{nmol} \mathrm{cm}{ }^{-3}$ in the upper 0 to $2 \mathrm{~mm}$ in April, but decreased rapidly with depth and was negligible below $10 \mathrm{~mm}$. The pool gradually disappeared during the following 3 to $4 \mathrm{mo}$. The surface-located particulate $\mathrm{NO}_{3}^{-}$pool also increased strongly after the spring sedimentation when concentrations above 200 $\mathrm{nmol} \mathrm{cm}{ }^{-3}$ were recorded in the 0 to $2 \mathrm{~mm}$ segment (Fig, 6B). The pool was confined to the upper $5 \mathrm{~mm}$. A final depletion occurred in August as was the case for $\mathrm{NH}_{4}^{+}$. The period following spring sedimentation was characterized by a considerable patchiness of deposited material (Jensen et al. 1988, 1990), and the variability of the particulate $\mathrm{NH}_{4}^{+}$and $\mathrm{NO}_{3}^{-}$pools was generally high between cores. For instance, a few cores with dense layers of diatoms showed particulate pools 10 to 2

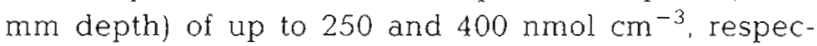
tively.

The seasonal pattern of depth-integrated particulate $\mathrm{NH}_{4}^{+}$and $\mathrm{NO}_{3}^{-}$pools (0 to $7 \mathrm{~mm}$ depth) are shown in Fig. 7. The distinct increase of both pools after the sedimentation event resulted in a 5 -fold higher total particulate $\mathrm{NH}_{4}^{+}$plus $\mathrm{NO}_{3}^{-}$pool. The total pool was high during spring and early summer, although each of the

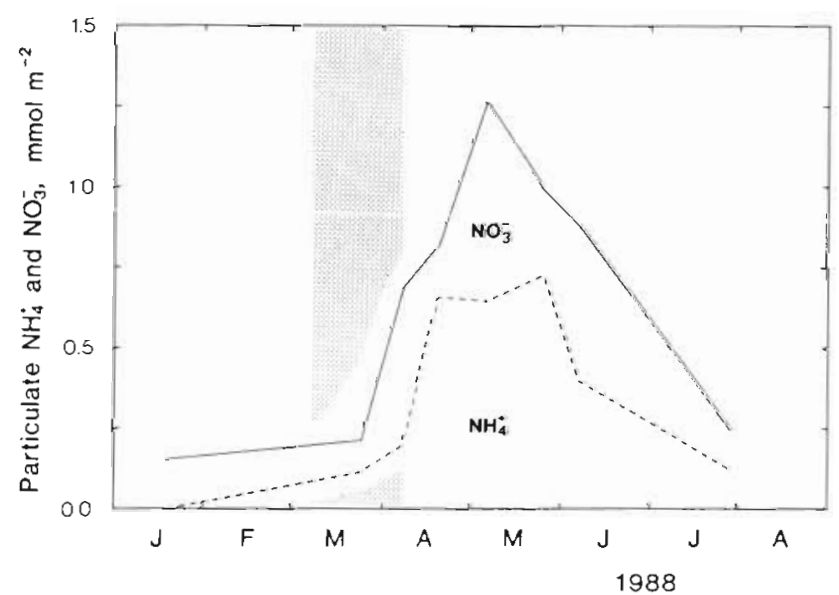

Fig. 7. Depth-integrated pool sizes $(0$ to $7 \mathrm{~mm}$ depth) of particulate (intracellular) $\mathrm{NH}_{4}^{-}$(below broken line) and $\mathrm{NO}_{3}^{-}$ (above broken line) in Aarhus Bight sediment (Stn 16) during 1988. Shaded area as in Fig. 5 contributing $\mathrm{NH}_{4}^{+}$and $\mathrm{NO}_{3}^{-}$pools showed considerable oscillations during this period. The gradual decrease of the total pool during summer occurred at the expense of both $\mathrm{NH}_{4}^{+}$and $\mathrm{NO}_{3}^{-}$.

\section{DISCUSSION}

\section{Extraction and origin of $\mathrm{NH}_{4}^{+}$and $\mathrm{NO}_{3}^{-}$pools in the sediment}

Besides being dissolved in the pore water, $\mathrm{NH}_{4}^{+}$may be bound to the sediment matrix in an exchangeable pool which can be extracted by cations such as $\mathrm{K}^{+}$. The dynamic nature of the exchangeable $\mathrm{NH}_{4}^{+}$pool implies that it might play a significant role in sediment nitrogen cycling, for instance by retaining $\mathrm{NH}_{4}^{+}$otherwise available for diffusion flux (Blackburn \& Henriksen 1983). Throughout the investigation period, the exchangeable $\mathrm{NH}_{4}^{+}$concentration generally increased with depth in the sediment, and the pool size 10 to $4 \mathrm{~cm}$ depth) ranged from a factor of ca 0.5 to 2 of the pore water pool showing no specific seasonal pattern (data not shown). The observed range is within the range reported for other marine sediments (Blackburn \& Henriksen 1983, Mackin \& Aller 1984).

A particulate $\mathrm{NH}_{4}^{+}$pool, extractable by freezing in liquid $\mathrm{N}_{2}$ but not in $\mathrm{KCl}$, was found in the uppermost part of the sediment. The particulate pool was relatively large compared to the pore water and exchangeable pools and appeared immediately after the spring bloom sedimentation (Fig. 6A). Intracellular $\mathrm{NH}_{4}^{+}$pools have been described for planktonic diatoms, both in cultures and in situ (Dortch 1982, Thoresen et al. 1982, Dortch et al. 1984, Dortch et al. 1985), and Thoresen et al. (1982) found that treatment with liquid $\mathrm{N}_{2}$ efficiently ruptures algal cells. Based on this evidence, we ascribe the surface-located particulate pool to an intracellular pool in the deposited diatoms. In the following we therefore refer to a pool of intracellular $\mathrm{NH}_{4}^{+}$in the surface sediment. Deeper in the sediment, the intracellular $\mathrm{NH}_{4}^{+}$pool appeared to be absent, since the freezing technique extracted a similar or slightly smaller a mount of $\mathrm{NH}_{4}^{+}$than the $\mathrm{KCl}$ extraction (Fig. 3A; Yamada et al. 1987).

It was unlikely that the measured particulate $\mathrm{NO}_{3}^{-}$ originated from an exchangeable (adsorbed) pool, although non-specifjc binding of $\mathrm{NO}_{3}^{-}$within an electrical double layer is theoretically possible (e.g. Wang et al. 1987). The affinity for such adsorption sites must be stronger for $\mathrm{Cl}^{-}$than for $\mathrm{NO}_{3}^{-}$ions, however, and marine sediments typically contain 1000 -fold more $\mathrm{Cl}^{-}$than $\mathrm{NO}_{3}^{-}$. The various treatments (II to IV) used in the present study extracted $\mathrm{NO}_{3}^{-}$from a single particulate pool in the sediment, and the largest pool size was measured in the period immediately after bloom sedimentation (Fig. 6B). 
This was in good agreement with the existence of a particulate pool associated with intracellular $\mathrm{NO}_{3}^{-}$in deposited microalgae. Diatoms such as Skeletonema costatum, which may be dominant in spring blooms of temperate coastal waters, can store large amounts of $\mathrm{NO}_{3}^{-}$in batch cultures (e.g. Dortch 1982, Raimbault \& Mingazzini 1987), and Dortch et al. (1985) measured high in situ concentrations of intracellular $\mathrm{NO}_{3}^{-}$in natural assemblages of phytoplankton during a spring bloom. As for $\mathrm{NH}_{4}^{+}$, we shall therefore refer to an intracellular $\mathrm{NO}_{3}^{-}$pool in the sediment. Treatments with liquid $\mathrm{N}_{2}$ and ethanol extracted the same quantity of intracellular $\mathrm{NO}_{3}^{-}$(Fig. 4) after the algal cells were ruptured. Ethanol has not previously been used for extraction of intracellular $\mathrm{NO}_{3}^{-}$, but we suppose that the microalgae were ruptured due to a dramatic change in osmotic pressure. The $\mathrm{KCl}$ extraction was less efficient in releasing intracellular $\mathrm{NO}_{3}^{-}$(Fig. 3B). Garber (1984) found $\mathrm{KCl}$-extractable $\mathrm{NO}_{3}^{-}$concentrations of about 50 nmol $\mathrm{cm}^{-3}$ in Narragansett Bay (RI, USA) sediment, but no detectable $\mathrm{NO}_{3}^{-}$in the pore water. However, the origin or significance of this $\mathrm{KCl}$-extractable $\mathrm{NO}_{3}^{-}$pool was not discussed.

A drawback of the presented techniques is a weak distinction between $\mathrm{KCl}$-extractable and intracellular $\mathrm{NH}_{4}^{+}$. However, the high intracellular $\mathrm{NH}_{4}^{+}$concentrations measured at the very surface was not in serious error, but the intracellular $\mathrm{NH}_{4}^{+}$pool at depth could be underestimated. Further refinement of the method for deeper layers is needed. Comparing various methods for determination of intracellular pools of inorganic nitrogen in microalgae, Thoresen et al. (1982) considered boiling water extraction as the most efficient. We used the freezing technique because it is easy, rapid and requires no addition of solutes.

In light of the present demonstration of particulate, intracellular $\mathrm{NH}_{4}^{+}$and $\mathrm{NO}_{3}^{-}$pools in sediments, care has to be taken when determining $\mathrm{NH}_{4}^{+}$and $\mathrm{NO}_{3}^{-}$concentrations in marine sediments, especially in those characterized by sedimentation of planktonic blooms or high densities of benthic diatoms. $\mathrm{A} \mathrm{KCl}$ extraction of surface sediment (Henriksen et al. 1980, Andersen et al. 1984, Jørgensen \& Sørensen 1985, Jørgensen \& Sørensen 1988) and a liquid $\mathrm{N}_{2}$ freezing procedure for conservation purposes (Sørensen 1978) are not recommended if the samples are to be assayed for dissolved $\mathrm{NO}_{3}^{-}$. The $\mathrm{NO}_{3}^{-}$ concentration obtained may thus include an intracellular $\mathrm{NO}_{3}^{-}$pool and result in erroneous estimates of pore water $\mathrm{NO}_{3}^{-}$. On the other hand, freezing in liquid $\mathrm{N}_{2}$ may provide a satisfactory estimate of intracellular $\mathrm{NH}_{4}^{+}$and $\mathrm{NO}_{3}^{-}$pools in sediments when combined with separate determination of $\mathrm{NO}_{3}^{-}$and $\mathrm{NH}_{4}^{+}$in the pore water and in the $\mathrm{KCl}$-extractable fraction. The freezing assay may also be useful as an indicator of sedimentation of phytoplankton blooms in shallow marine areas.

\section{Seasonal pattern of $\mathrm{NH}_{4}^{+}$and $\mathrm{NO}_{3}^{-}$pools}

The profiles shown in Fig. 5 represent the first seasonal pattern of pore water $\mathrm{NH}_{4}^{+}$and $\mathrm{NO}_{3}^{-}$concentrations measured at mm-resolution in a marine surface sediment. The input of an easy-degradable pool of phytodetritus to the sediment in early spring resulted in distinct changes in the benthic $\mathrm{NH}_{4}^{+}$and $\mathrm{NO}_{3}^{-}$flux at Stn 16 (Jensen et al. 1990). Thus, both the highly increased release of $\mathrm{NH}_{4}^{+}$and the shift from a modest release to a high uptake of $\mathrm{NO}_{3}^{-}$in the sediment between March and April corresponded well to the changes in the interfacial gradients shown in Fig. 5. Accordingly, the accumulation of $\mathrm{NH}_{4}^{+}$and decrease of $\mathrm{NO}_{3}^{-}$in the surficial pore water pool immediately after the spring sedimentation was apparently a result of increased mineralization and reduced $\mathrm{O}_{2}$ penetration, which limited nitrification and increased $\mathrm{NO}_{3}^{-}$ consumption (denitrification) (Jensen et al. 1988, $1990)$.

Sedimentation of the phytoplankton bloom in early spring represents a mass transfer of nitrogen from the water column to the sediment in the form of detrital nitrogen, but also as particulate, intracellular pools of $\mathrm{NH}_{4}^{+}$and $\mathrm{NO}_{3}^{-}$in live diatoms. However, the role of the live fraction of the deposited diatoms in the sediment nitrogen cycle is poorly known. In shallow estuaries where light is sufficient, inorganic nitrogen assimilation and photosynthetic $\mathrm{O}_{2}$ production by benthic diatoms profoundly affect the $\mathrm{NH}_{4}^{+}$and $\mathrm{NO}_{3}^{-}$flux, nitrification and denitrification (Henriksen et al. 1980, Andersen et al. 1984, Granéli \& Sundbäck 1985, Nowicki \& Nixon 1985, Henriksen \& Kemp 1988, Jørgensen \& Sørensen 1988). Only a few studies have looked for such interactions in coastal, light-limited sediments at greater water depth, however. Diatoms, which sink out of the surface waters, may continue their assimilation in the often nutrient-rich bottom waters or at the sediment surface. It has been proposed that mass sinking of diatoms is a survival reaction when surface waters are depleted in nutrients (Smetacek 1985), and recent evidence suggests that mass flocculation of live diatoms is a widespread mechanism by which their sinking rate increases several-fold (Kranck \& Milligan 1988, Alldredge \& Gotschallk 1989). The sedimentation may represent a transition phase from a pelagic to a benthic stage in the life history cycle of such diatoms (Noji et al. 1986). Various investigations in light-limited Kattegat sediments (14 to $16 \mathrm{~m}$ depth) indicate that viable Skeletonema costatum cells deposited in early spring and benthic species developing in the summer are responsible for significant photosynthetic $\mathrm{O}_{2}$ production (Sundbäck \& Jonssön 1988), which even may exceed the sediment $\mathrm{O}_{2}$ uptake (Granéli \& Sundbäck 1986, Jørgensen \& Revsbech 1989), and that micro- 
phytobenthic $\mathrm{O}_{2}$ production and nutrient assimilation are major determinants of the direction and magnitude of the $\mathrm{NH}_{4}^{+}$flux (Blackburn \& Henriksen 1983, Sundbäck \& Granéli 1988). Riaux-Gobin et al. (1989) assigned decreases of pore water $\mathrm{NH}_{4}^{+}$and $\mathrm{NO}_{3}$ to microphytobenthic assimilation during a spring bloom in a subtidal sand at $20 \mathrm{~m}$ depth

Microscopic inspection of the Aarhus Bight sediment in April revealed that a large fraction of the deposited diatoms, notably Skeletonema costatum, was still viable. They may have continued assimilation of $\mathrm{NH}_{4}^{+}$and $\mathrm{NO}_{3}^{-}$, thereby sustaining the large intracellular pools for 3 to 4 mo after the initial increase. The actual gradients and availability of $\mathrm{NH}_{4}^{+}$and $\mathrm{NO}_{3}^{-}$experienced by the diatoms at the very surface may be difficult to determine, but the presence of high levels of intracellular $\mathrm{NH}_{4}^{+}$and $\mathrm{NO}_{3}^{-}$indicated that the diatoms not were deficient in nitrogen during this period (Dortch et al. 1985). Whereas deposited planktonic diatoms are responsible for the initial increase of the intracellular pools at Stn 16 in April, populations of benthic diatoms may have contributed to the maintenance of the large pools throughout summer. Benthic species, e.g. of the genus Nitzchia, were in fact identified in the surface sediment although in smaller numbers than the pelagic species.

Later in summer, both intracellular pools decreased considerably (Figs. 6 and 7). However, the mechanism responsible for the decrease is not clear. Likely explanations include excretion or incorporation of the intracellular pools or microbial degradation of the microalgae. During fall when the intracellular pools almost disappeared, light conditions probably became further unfavourable for growth of the microphytobenthic community. Planktonic diatoms are able to survive for very long periods in the dark as vegetative or resting cells (Smayda \& Mitchell-Innes 1974, Durbin 1978, Sicko-Goad et al. 1989), even in deep sediment strata (Wasmund 1989). It is not known whether $\mathrm{NH}_{4}^{+}$ and $\mathrm{NO}_{3}^{-}$pools are maintained in the intracellular volume under such conditions, but it was suggested by Wasmund (1989) that microalgae buried in the sediment survive by drawing slowiy on their internal reserves.

The present study demonstrates the existence of large, particulate pools of inorganic nitrogen which developed after extensive sedimentation of a spring phytoplankton bloom. The particulate $\mathrm{NH}_{4}^{+}$and $\mathrm{NO}_{3}^{-}$ was ascribed to intracellular pools in deposited microalgae and possibly, to a lesser extent, in benthic diatoms. The role of these pools and of the possible microphytobenthic activity (i.e. nutrient assimilation and $\mathrm{O}_{2}$ production) for the nitrogen cycling in lightlimited, marine sediments is, however, not well understood.
Acknowledgements. We are indebted to Hans Jensen on board 'Genetica' for helpful assistance during sampling and to Dorthe Olsson who skillfully performed many of the chemical analyses. Thanks are due to Bente Aa. Lomstein for valuable discussions and assistance with drawings and to Erik Kristensen for critically reading the manuscript. This study was supported by the National Agency for Environmental Protection under the Danish Ministry of the Environment.

\section{LITERATURE CITED}

Alldredge, A. L., Gotschalk, C. C. (1989). Direct observations of the mass flocculation of diatom blooms: characteristics, seltling velocities and formation of diatom aggregates. Deep Sea Res. 36: 159-171

Andersen, T. K., Jensen, M. H., Serensen, J. (1984). Diurnal variation of nitrogen cycling in coastal, marine sediments. I. Denitrification. Mar. Biol. 83: 171-176

Armstrong, F. A., Stearns, C. R., Strickland, J. D. (1967). The measurement of upwelling and subsequent biological processes by means of the Technicon Autoanalyzer and associated equipment. Deep Sea Res. 14: 381-389

Blackburn, T H., Henriksen, K. (1983). Nitrogen cycling in different types of sediment from Danish waters. Limnol. Oceanogr 28: 477-493

Bremner, J. M., Nelson, W. D., Silva, J. A. (1967). Comparison and evaluation of methods of determining fixed ammonium in soils. Soil Sci. Soc. Am. Proc. 31: 456-472

Dortch, Q. (1982). Effect of growth conditions on accumulation of internal nitrate, ammonium, amino acids, and proteins in three marine diatoms. J. exp. mar Biol. Ecol. 61. 243-264

Dortch, Q., Clayton, J. R., Thoresen, S. S., Ahmed, S. I. (1984). Species differences in accumulation of nitrogen pools in phytoplankton. Mar. Biol. 81: 237-250

Dortch, Q., Clayton, J. R., Thoresen, S. S., Cleveland, J. S., Bressler, S. L., Ahmed, S. I. (1985). Nitrogen storage and use of biochemical indices to assess nitrogen deficiency and growth rate in natural phytoplankton populations. J. mar Res. 43: 437-464

Durbin, E. G. (1978). Aspects of the biology of resting spores of Thalassiosira nordenskioeldii and Detonula confervacea. Mar Biol. 45: 31-37

Garber, J. H. (1984). ${ }^{15} \mathrm{~N}$ study of the short-term fate of particulate organic nitrogen at the surface of coastal marine sediments. Mar. Ecol. Prog. Ser 16: 89-104

Granéli, E. Sundbäck, K. (1985). The response of planktonic and microbenthic algal assemblages to nutrient enrirhment in shallow coastal waters, southwest Sweden. J. cxp. mar. Biol. Ecol. 85: 253-268

Granéli. W., Sundbäck, K. (1986). Can microbenthic photosynthesis influence below-halocline oxygen conditions in the? Kattegat? Ophelia 26: 195-206

Henriksen, K., Hansen, J. I., Blackburn, T H. (1980). The influence of benthic infauna on exchange rates of inorganic nitrogen between sediment and water. Ophelia, suppl. 1: 249-256

Henriksen, K., Kemp, W. M. (1988). Nitrification in estuarine and coastal marine sediments. In: Blackburn, T. H., Sørensen, J. (eds.) Nitrogen cycling in codstal marine environments. John Wiley \& Sons, Chichester, p. 207-249

Jensen, M. H., Andersen, T. K., Sørensen, J. (1988). Denitrification in coastal bay sediment: regional and seasonal variation in Aarhus Bight, Denmark. Mar. Ecol. Prog. Ser. 48: $155-162$ 
Jensen, M. H., Lomstein, E., Serensen, J. (1990). Benthic $\mathrm{NH}_{4}^{+}$ and $\mathrm{NO}_{3}^{-}$flux following sedimentation of a spring phytoplankton bloom in Aarhus Bight, Denmark. Mar. Ecol. Prog. Ser. 61 87-96

Jorgensen, B. B., Revsbech, N. P. (1989). Oxygen uptake, bacterial distribution and carbon-nitrogen-sulfur cycling in sediments from the Baltic Sea-North Sea transition Ophelia 31. 29-49

Jørgensen, B. B., Sørensen, J. (1985). Seasonal cycles of $\mathrm{O}_{2}$ $\mathrm{NO}_{3}^{-}$and $\mathrm{SO}_{4}^{2-}$ reduction in estuarine sediments: the sig nificance of an $\mathrm{NO}_{3}^{-}$reduction maximum in spring. Mar. Ecol. Prog. Ser 24: 65-74

Jørgensen, K. S., Serensen, J. (1988). Two annual maxima of nitrate reduction and denitrification in estuarine sediment (Norsminde Fjord, Denmark). Mar. Ecol. Prog. Ser 48: $147-154$

Kanneworff, E., Nicolaisen, W. (1973). The 'Haps', a frame supported bottom corer. Ophelia 10: 119-128

Kranck, K., Milligan, T. G. (1988). Macroflocs from diatoms: in situ photograph of particles in Bedford Basin. Nova Scotia. Mar. Ecol. Prog. Ser. 44: 183-189

Mackin, J. E., Aller, R. C. (1984). Ammonium adsorption in marine sediments. Limnol. Oceanogr. 29: 250-257

Noji, T., Passow, U., Smetacek, V. (1986). Interactions between pelagial and benthal during autumn in Kiel Bight I. Development and sedimentation of phytoplankton blooms. Ophelia 26: 333-349

Nowicki, B. L., Nixon, S. W. (1985). Benthic nutrient remineralization in a coastal lagoon ecosystem. Estuaries 8: $182-190$

Pett, R. J. (1989). Kinetics of microbial mineralization of organic carbon from detrital Skeletonema costatum cells. Mar Ecol. Prog. Ser. 52: 123-128

Raimbault, P., Mingazinni, M. (1987). Diurnal variations of intracellular nitrate storage by marine diatoms: effects of nutritional state. J. exp. mar. Biol. Ecol. 112: 217-232

Riaux-Gobin, C., Douchement, C., Tréguer, P. (1989). Microphytobenthos de deux sédiments subtidaux de Nord Bretagne. III. Relations avec les sels minéraux azotés de

This article was submitted to the editor l'eau interstitielle et deux facteurs hydroclimatique. Hydrobiologia 178: 11-20

Rosenfeld, J. K. (1979). Ammonium adsorption in nearshore anoxic sediments. Limnol. Oceanogr 24: 356-364

Sicko-Goad, L.. Stoermer, E. F., Kociolek, J. P. (1989). Diatom resting rell rejuvencition and formation: time course, species records and distribution. J. Plankton Res. 11: 375-389

Smayda, T J., Mitchell-Innes, B. (1974). Dark survival of autotrophic, planktonic marine diatoms. Mar Biol. 25 195-202

Smetacek, V (1985). Role of sinking in diatom life-history cycles: ecological, evolutionary and geological significance. Mar. Biol. 84: 239-251

Solorzano, L. (1969). Determination of ammonia in natural waters by the phenol-hypochlorite method. Limnol. Oceanogr 14: 799-801

Sorensen, J. (1978). Denitrification rates in a marine sediment as measured by the acetylene inhibition technique. Appl environ. Microbiol. 36: 139-143

Sundbäck, K., Granéli, W. (1988). Influence of microphytobenthos on the nutrient flux between sediment and water: a laboratory study. Mar Ecol. Prog. Ser 43: 63-69

Sundbäck, K., Jönsson, B. (1988). Microphytobenthic productivity and biomass in sublittoral sediments of a stratified bay southeastern Kattegat. J. exp. mar Biol. Ecol. 122: 63-81

Thoresen, S. S., Dortch, Q. Ahmed, S. I. (1982). Comparison of methods for extraction of inorganic nitrogen pools from marine phytoplankton. J. Plankton Res. 4: 195-204

Wang, P. G., Ji, G. L., Yu, T R. (1987). Adsorption of chloride and nitrate by variable charge in relation to the electric charge of the soil. Z. Pflanzenernähr. Bodenkd. 150: 17-23

Wasmund, N. (1989). Micro-autoradiographic determination of the viability of algae inhabiting deep sediment layers Estuar coast. Shelf Sci. 28: 651-656

Yamada, H., Kayama, M., Fujisawa, K. (1987). Seasonal changes of concentrations of inorganic and organic nitrogen in coastal marine sediments. Estuar. coast. Shelf Sci 24: $585-598$

Manuscript first received: June 27, 1989

Revised version accepted: December 21, 1989 